\title{
Comparison of the exotic and native ant communities (Hymenoptera: Formicidae) in urban green areas at inland, coastal and insular sites in Spain
}

\author{
JOAQUín REYES-LÓPEZ and SOLEDAD CARPINTERO
}

Ecology Area, University of Cordoba, Edificio C-4 “Celestino Mutis”, Campus de Rabanales, Ctra. Madrid, Km. 396, 14071 Cordoba, Spain; e-mails: joaquin@uco.es; solecarpintero@gmail.com

Key words. Hymenoptera, Formicidae, ants, urban ecology, exotic species, community biogeography

\begin{abstract}
Currently the introduction and spread of invasive species is an issue of great concern. To effectively manage this problem it is essential to know what constitute invasion hotspots. In this respect, the role of urban green areas in the conservation of biodiversity is a controversial matter. These areas may either favour colonization by alien species or shelter species of high conservation value. We evaluated the influence of location (island, coastal or inland) on the exotic and native ant fauna recorded in 27 urban green areas in Spain. A forward-stepwise discriminant analysis revealed differences between these locations in terms of the composition of the fauna, with exotic species identified as being the most important discriminating variable. There is a gradient: inland-coastal-island, along which there is significant increase in importance in terms of species richness and abundance of particular exotic species and decrease in the dominance of both common and rare native species. Areas located on the Island were more susceptible to invasion by alien ants. Coastal areas were also more susceptible to invasion than inland areas. These results possibly reflect the greater probability of an invasive species reaching these locations and the milder weather conditions at these sites, which would favour their establishment.
\end{abstract}

\section{INTRODUCTION}

The loss of natural habitats due to increasing urbanization constitutes one of the biggest problems for the conservation of species. Today, almost half of humanity lives in urban areas and by the year 2050 urban areas are expected to be home to more than two thirds of the world's population (United Nations, 2010). In the face of urban sprawl, native species either adapt or disappear. There are some species that are preadapted to living in humanized habitats and many studies report homogenization of the fauna in these habitats (McKinney, 2006; Lizée et al., 2011; Buczkowski \& Richmond, 2013). Exotic species are frequently favoured by these circumstances (Reyes-López et al., 2008; Stringer et al., 2009), a fact which aggravates the situation of native species (Lososová et al., 2012).

Other studies indicate that urban environments are not lost habitats for wildlife but rather new habitats that, with the proper management, have the potential to support diverse communities (Sattler et al., 2011; Trueman \& Young, 2012). In particular, urban parks and gardens are possible refuges for native species of animals and plants (Adams, 1994). Many publications have sought to discover the characteristics of these green islands that help to maintain diverse communities, by providing space for conservation, restoration and reconciliation ecology (see for example in: Adams, 1994; Nilton, 2011). In summary, a controversy surrounds the true value of urban habitats for conservation purposes and much local work on this topic needs to be done.

Ants commonly feature in urban studies due to their abundance in these habitats (McIntyre et al., 2001; Whitmore et al., 2002) and their values as bioindicators (Brown 1997; Dekoninck et al., 2008; Ribas et al., 2012; Slipinski et al., 2012). In general, because of their ecological dominance they play crucial roles in ecosystems as predators, scavengers and indirect herbivores (Wilson \& Hölldobler, 2005). In addition, invasive ants have received a great deal of attention. Some of them are among the most ubiquitous and harmful invaders worldwide (Berman et al., 2013) and are particularly dangerous on islands (see examples in Williams, 1994 and in Holway et al., 2002). Island and coastal areas are very sensitive to invasion by exotic species (Martínez et al., 2007), but, it is unknown whether this is true of urban areas or if the level of faunal homogenization is such that the location of the urban green area does not affect the composition of the community. Numerous studies have examined the effect of exotic species of ants on islands and, additionally, there is a growing interest in understanding the effect of urbanization on ant communities. However, no study has identified an explicit connection between urbanization and the coastal or continental character of specific habitats, such as urban green areas, on ant communities. The current study compares the percentage of exotic versus native species of ants in inland, continental coastal and island urban green areas over a wide geographic area of Spain and identifies important species in terms of conservation.

\section{MATERIAL AND METHODS}

\section{Study sites}

We sampled 27 urban green spaces at three different locations: in the main Andalusian coastal cities of Huelva, Cadiz, Malaga and Almeria; the Spanish island Gran Canaria; and two major inland cities along the river Guadalquivir, Seville and Cordoba. The last two cities were selected because rivers constitute natural corridors that promote the dispersion of many exotic species (Roura- 
TABLE 1. Location of urban green spaces studied, type of locality and number of transects with 10 pitfall traps.

\begin{tabular}{|c|c|c|c|c|}
\hline Park & Province & Coordinates GPS & Type of locality & No. of transects \\
\hline Colegio Mayor de la Asunción Gardens & Cordoba & $37^{\circ} 52^{\prime} 01.66^{\prime \prime} \mathrm{N}-4^{\circ} 47^{\prime} 40.26^{\prime \prime} \mathrm{W}$ & Inland & 10 \\
\hline Cruz Conde Park & Cordoba & $37^{\circ} 52^{\prime} 19.56^{\prime \prime} \mathrm{N}-4^{\circ} 47^{\prime} 22.49^{\prime \prime} \mathrm{W}$ & Inland & 7 \\
\hline Paseo de Córdoba Gardens & Cordoba & $37^{\circ} 53^{\prime} 27.24^{\prime \prime} \mathrm{N}-4^{\circ} 47^{\prime} 01.00^{\prime \prime} \mathrm{W}$ & Inland & 15 \\
\hline Dr. Alfonso Carpintero Park & Cordoba & $37^{\circ} 53^{\prime} 54.50^{\prime \prime} \mathrm{N}-4^{\circ} 45^{\prime} 57.55^{\prime \prime} \mathrm{W}$ & Inland & 9 \\
\hline Vallellano Gardens & Cordoba & $37^{\circ} 52^{\prime} 40.70^{\prime \prime} \mathrm{N}-4^{\circ} 47^{\prime} 07.95^{\prime \prime} \mathrm{W}$ & Inland & 7 \\
\hline Escritora Elena Fortún Park & Cordoba & $37^{\circ} 52^{\prime} 39.21^{\prime \prime} \mathrm{N}-4^{\circ} 47^{\prime} 57.67^{\prime \prime} \mathrm{W}$ & Inland & 6 \\
\hline Miraflores Park & Seville & $37^{\circ} 24^{\prime} 41.99^{\prime \prime} \mathrm{N}-5^{\circ} 58^{\prime} 00.06^{\prime \prime} \mathrm{W}$ & Inland & 5 \\
\hline Chapina Gardens & Seville & $37^{\circ} 23^{\prime} 15.59^{\prime \prime} \mathrm{N}-6^{\circ} 00^{\prime} 10.51^{\prime \prime} \mathrm{W}$ & Inland & 5 \\
\hline El Valle Gardens & Seville & $37^{\circ} 23^{\prime} 43.93^{\prime \prime} \mathrm{N}-5^{\circ} 58^{\prime} 58.31^{\prime \prime} \mathrm{W}$ & Inland & 5 \\
\hline María Luisa Park & Seville & $37^{\circ} 22^{\prime} 31.99^{\prime \prime} \mathrm{N}-5^{\circ} 59^{\prime} 27.22^{\prime \prime} \mathrm{W}$ & Inland & 12 \\
\hline Alamillo Park & Seville & $37^{\circ} 24^{\prime} 54.70^{\prime \prime} \mathrm{N}-5^{\circ} 59^{\prime} 38.13^{\prime \prime} \mathrm{W}$ & Inland & 13 \\
\hline Gardens of the University Pablo de Olavide & Seville & $37^{\circ} 21^{\prime} 36.37^{\prime \prime} \mathrm{N}-5^{\circ} 56^{\prime} 30.61^{\prime \prime} \mathrm{W}$ & Inland & 6 \\
\hline Gardens of Alcazaba & Malaga & $36^{\circ} 43^{\prime} 28.00^{\prime \prime} \mathrm{N}-4^{\circ} 24^{\prime} 92.29^{\prime \prime} \mathrm{W}$ & Coast & 2 \\
\hline Gibralfaro gardens & Malaga & $36^{\circ} 43^{\prime} 24.76^{\prime \prime} \mathrm{N}-4^{\circ} 24^{\prime} 38.56^{\prime \prime} \mathrm{W}$ & Coast & 1 \\
\hline Paloma park & Malaga & $36^{\circ} 35^{\prime} 60.95^{\prime \prime} \mathrm{N}-4^{\circ} 31^{\prime} 72.25^{\prime \prime} \mathrm{W}$ & Coast & 7 \\
\hline Picasso gardens & Malaga & $36^{\circ} 43^{\prime} 00.11^{\prime \prime} \mathrm{N}-4^{\circ} 26^{\prime} 07.67^{\prime \prime} \mathrm{W}$ & Coast & 16 \\
\hline El Muelle gardens & Huelva & $37^{\circ} 15^{\prime} 34.42^{\prime \prime} \mathrm{N}-6^{\circ} 57^{\prime} 49.93^{\prime \prime} \mathrm{W}$ & Coast & 2 \\
\hline El Boticario park & Almeria & $36^{\circ} 51^{\prime} 83.83^{\prime \prime} \mathrm{N}-2^{\circ} 23^{\prime} 36.26^{\prime \prime} \mathrm{W}$ & Coast & 6 \\
\hline Costa Ballena gardens & Cadiz & $36^{\circ} 41^{\prime} 43.45^{\prime \prime} \mathrm{N}-6^{\circ} 24^{\prime} 47.56^{\prime \prime} \mathrm{W}$ & Coast & 11 \\
\hline Guadalete river gardens & Cadiz & $36^{\circ} 35^{\prime} 54.72^{\prime \prime} \mathrm{N}-6^{\circ} 13^{\prime} 23.80^{\prime \prime} \mathrm{W}$ & Coast & 1 \\
\hline Camping "Las Dunas" gardens & Cadiz & $36^{\circ} 35^{\prime} 15.40^{\prime \prime} \mathrm{N}-6^{\circ} 14^{\prime} 27.37^{\prime \prime} \mathrm{W}$ & Coast & 1 \\
\hline El Polvorista square gardens & Cadiz & $36^{\circ} 35^{\prime} 69.92^{\prime \prime} \mathrm{N}-6^{\circ} 13^{\prime} 63.85^{\prime \prime} \mathrm{W}$ & Coast & 1 \\
\hline La Feria square gardens & Las Palmas & $28^{\circ} 6^{\prime} 48.02^{\prime \prime} \mathrm{N}-15^{\circ} 25^{\prime} 13.97^{\prime \prime} \mathrm{W}$ & Insular & 3 \\
\hline San Telmo park & Las Palmas & $28^{\circ} 6^{\prime} 31.19^{\prime \prime} \mathrm{N}-15^{\circ} 25^{\prime} 0.75^{\prime \prime} \mathrm{W}$ & Insular & 1 \\
\hline Parque Romano & Las Palmas & $28^{\circ} 7^{\prime} 28.85^{\prime \prime} \mathrm{N}-15^{\circ} 25^{\prime} 37.32^{\prime \prime} \mathrm{W}$ & Insular & 4 \\
\hline Veterinary Faculty gardens (Arucas) & Las Palmas & $28^{\circ} 8^{\prime} 20.31^{\prime \prime} \mathrm{N}-15^{\circ} 30^{\prime} 21.88^{\prime \prime} \mathrm{W}$ & Insular & 2 \\
\hline Parque de Cardones & Las Palmas & $28^{\circ} 7^{\prime} 56.64^{\prime \prime} \mathrm{N}-15^{\circ} 30^{\prime} 45.27^{\prime \prime} \mathrm{W}$ & Insular & 1 \\
\hline
\end{tabular}

Pascual et al., 2009; Säumel \& Kowarik, 2010). Locations of the urban green spaces studied are in Table 1.

All of the urban green spaces are municipal gardens, located within residential areas. Although there are slight differences in their internal structure, current ways of gardening lead to a general resemblance, with extensive lawns and dispersed trees and bushes.

Andalusian coast has a coastal Mediterranean climate with dry warm summers and mild winters, softened by the influence of the sea. Cordoba and Seville have a hot inland Mediterranean climate with temperate winters and dry hot summers, with some of the highest European temperature records. Climate of Gran Canaria is subtropical with constant warm temperatures throughout the year and little rain (Climate data in Table 2).

TABLE 2. Climate of the provinces in which the study sites are located. $\mathrm{T}$ - mean annual temperature $\left({ }^{\circ} \mathrm{C}\right) ; \mathrm{TM}$ - mean daily maximum temperature $\left({ }^{\circ} \mathrm{C}\right) ; \mathrm{Tm}$ - mean daily minimum temperature $\left({ }^{\circ} \mathrm{C}\right) ; \mathrm{P}-$ mean annual precipitation $(\mathrm{mm}) ; \mathrm{H}-$ mean relative humidity (\%). Data from AEMET (State Meteorology Agency). Period 1971-2000.

\begin{tabular}{lccccc}
\hline Province & $\mathrm{T}$ & $\mathrm{TM}$ & $\mathrm{Tm}$ & $\mathrm{P}$ & $\mathrm{H}$ \\
\hline Cordoba & 17.6 & 24.6 & 10.7 & 536 & 62 \\
Seville & 18.6 & 24.9 & 12.2 & 534 & 61 \\
Huelva & 18.1 & 23.5 & 12.7 & 490 & 64 \\
Cadiz & 17.7 & 23.9 & 11.6 & 598 & 67 \\
Malaga & 18.0 & 22.9 & 13.1 & 524 & 66 \\
Almeria & 18.7 & 23.1 & 14.3 & 196 & 66 \\
Las Palmas & 20.7 & 23.8 & 17.7 & 134 & 68 \\
\hline
\end{tabular}

\section{Sampling techniques}

To estimate ant abundance and species richness, we sampled the urban green areas using pitfall traps. Pitfall traps are considered to be an effective way of obtaining a representative sample of ant communities and are recommended as part of the standard protocol for measuring biodiversity (Agosti et al., 2000; Clarke et al., 2008). Traps were sunk into the ground with the tops flush with soil surface. Each trap consisted of a $100 \mathrm{ml}$ plastic container, $6 \mathrm{~cm}$ wide (internal diameter of opening) (REF. 409702, DELTALAB SL.) filled with $25 \mathrm{ml}$ of water and a few drops of detergent to lower surface tension. They stayed open in the field for $48 \mathrm{~h}$. The sampling periods at all 27 sites were in the springs and summers of the years 2003-2006 and 2010. At these latitudes, ants are most active in these seasons (Jimenez \& Tinaut, 1992; Carpintero et al., 2007).

Urban green areas were sampled using different numbers of pitfall traps, depending on the area sampled, in order maximize the number of species trapped (see species-accumulation curves Fig. 1). They were set at 2-meter intervals along linear transects, each comprising 10 traps, and placed in such a way to include the maximum number of microhabitats, making a total of 1560 traps. Each park was sampled only once. After collecting the traps, ants were extracted and stored in $70 \%$ ethanol. All specimens were identified to species and counted, with the exception the genus Solenopsis the taxonomy of which is still under debate in Europe (see Bernadou et al., 2013); therefore all native species of this genus are treated as a group. We only distinguished one exotic species of Solenopsis (X. Espadaler, pers. commun.).

Every species was assigned to one of three categories: (1) Exotic; (2) Native-common; (3) Native-rare. Rare species include those in Spain that have less than $10 \%$ of the citations (Magur- 


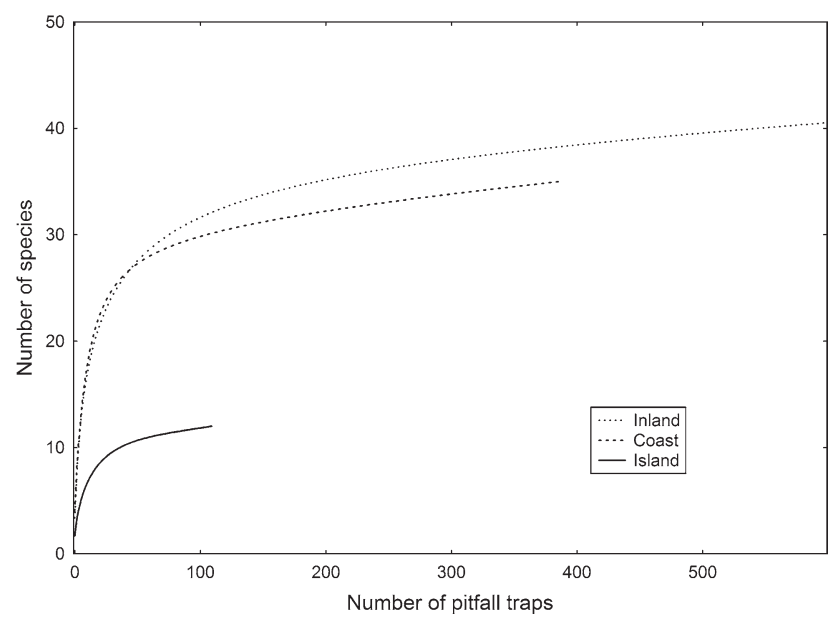

Fig. 1. Number of species recorded in the urban green areas at the three locations studied as a function of cumulative sampling effort - number of pitfall traps.

ran \& McGill, 2010) in the bibliography of Hormigas.org (2013). This a web site designed by ant specialists (X. Espadaler and K. Gómez), which includes a complete bibliography of Spanish ants. For every species of ant it gives how many times it has been cited in scientific papers. In natural environments it is universally the case that some species are very abundant, while the majority is rare or scarce (Magurran \& McGill, 2010). When the natural environment is perturbed, for example due to urbanization, this pattern can be affected. Usually, only certain species are able to survive the new conditions and so these species dominate while others become less abundant or disappear. Therefore, rare species (non abundant species) are considered to be indicators of healthy ecosystems.

\section{Statistical analyses}

A forward-stepwise discriminant analysis was performed to test if the fauna at the locations selected differed and, if so, to identify which of the species best distinguished the locations. To fulfill the statistical requirements, non-normally distributed variables (abundance of species) were transformed to natural logarithms. Individual sampling units for each of the analyses were the 10 pitfall trap transects.

To evaluate possible differences between the locations (inland, coastal and insular) chosen in terms of richness and total number of individuals of common, rare and exotic species, we performed two Kruskal-Wallis ANOVA tests on ranks. All analyses were carried out using the statistical package Statistica v7.1 (StatSoft, Tulsa, OK, USA).

\section{RESULTS}

A total of 44,930 ants were captured during this study, belonging to 23 genera and 55 species: 5,371 on Gran Canaria (120 traps); 11,877 along the coast (480 traps); and 27,682 in inland cities (1,000 traps). Eleven of the species were non-native. Native species were categorized as common (31 species) or rare (13 species) (Magurran \& McGill, 2010). Forty four species were trapped in urban green spaces inland (5 exotic and 12 rare, 11.36 and $27.27 \%$, respectively); 32 at coastal locations (8 exotic and 3 rare, 25.0 and $9.37 \%$, respectively); and 12 on Gran Canaria (6 exotic and 0 rare, 50.0 and $0 \%$, respectively).

The most abundant species at inland locations were: Lasius grandis, Tapinoma nigerrimum, Myrmica aloba,
Pheidole pallidula and Cardiocondyla mauritanica. At coastal locations some of the species were the same ( $T$. nigerrimum, P. pallidula, L. grandis), but there were also some exotic species: Solenopsis sp. (accounting for 8.89\% of individuals collected) and Nylanderia jaegerskioeldi $(6.16 \%)$. At the locations on the island, the four most abundant (97.92\% of individuals collected) were exotic species: Pheidole megacephala, N. jaegerskioeldi, Cardiocondyla emeryi and Paratrechina longicornis. The harmful invasive Argentine ant (Linepithema humile) was only found, in this study, at inland and coastal locations, and never abundant. Overall, the majority of the species were scarce with only a few of them very abundant (Table 3 ).

Results of a forward-stepwise discriminant analysis revealed differences between the locations selected (island, coastal and inland) in terms of the compositions of their fauna, with exotic species identified as being the most important discriminating variables (Table 4).

This study revealed the following gradient: inlandcoastal-island along which there is a significant increase in importance in terms of species richness and abundance of exotic species and decrease in dominance of native species (both common and rare species) (Table 5, Figs 2 and 3).

\section{DISCUSSION AND CONCLUSIONS}

In the present study, in all the areas sampled, the most abundant native species were: $T$. nigerrimum, L. grandis and $P$. pallidula. They are opportunistic, generalist and anthropophilic species, common in urban green areas in places with a Mediterranean climate (Carpintero \& ReyesLópez, 2014). Among the most abundant there were also some exotic species: $C$. mauritanica, which is widely distributed and high densities of P. megacephala, N. jaegerskioeldi and Solenopsis sp. on Gran Canaria and/or at coastal locations. In general, the majority of the species were scarce and only a few of them were very abundant (Table 3). It is a common phenomenon that certain species can be very abundant in urban habitats. In this regard, it is quite usual for tramp-species to have well populated nests (Passera, 1994; Holway et al., 2002). Furthermore, not only exotic but also native species can reach high densities in urban areas, usually because food is more abundant there (Ditchkoff et al., 2006; Shochat \& Ovadia, 2011). Generally, the consequences of urbanization are a reduction in species richness and homogenization in species composition. In this respect, some faunistic groups decrease or disappear, while others are favoured (McKinney, 2006; Shochat et al., 2006). Other urban studies record a large proportion of opportunistic and generalist species (Pisarski \& Czechowski, 1978; Vepsäläinen et al., 2008; Menke et al., 2011). Exotic species constitute one of the groups that are usually favoured, with consequent negative effects on biodiversity (Heterick et al., 2000; McKinney, 2006).

It is necessary to have the right environment if exotic ants are to thrive and become abundant (Krushelnycky et al., 2010). The regular watering of urban green areas, especially during hot, dry Mediterranean summers, converts these areas into "ant hospitable habitats" (Gómez \& Espa- 
TABLE 3. Percentage of the total number trapped ants made up of individuals of each of the species per locality studied, with each species categorized in terms of whether it is native or exotic and if native common or rare (Type).

\begin{tabular}{|c|c|c|c|c|}
\hline Species & Inland & Coast & Island & Type \\
\hline Aphaenogaster dulcinea Emery, 1924 & 0.01 & 0.00 & 0.00 & Native-rare \\
\hline Aphaenogaster gibbosa (Latreille, 1798) & 0.66 & 0.00 & 0.00 & Native-common \\
\hline Aphaenogaster iberica Emery, 1908 & 0.71 & 0.04 & 0.00 & Native-common \\
\hline Aphaenogaster senilis Mayr, 1853 & 2.88 & 1.31 & 0.00 & Native-common \\
\hline Camponotus fallax (Nylander, 1856) & 0.01 & 0.00 & 0.00 & Native-rare \\
\hline Camponotus piceus (Leach, 1825) & 0.01 & 0.00 & 0.00 & Native-common \\
\hline Camponotus pilicornis (Roger, 1859) & 0.68 & 0.15 & 0.00 & Native-common \\
\hline Cardiocondyla batesii Forel, 1894 & 0.03 & 0.00 & 0.00 & Native-rare \\
\hline Cardiocondyla elegans Emery, 1869 & 0.01 & 0.00 & 0.00 & Native-rare \\
\hline Cardiocondyla emeryi Forel, 1881 & 0.00 & 0.01 & 2.90 & Exotic \\
\hline Cardiocondyla mauritanica Forel, 1890 & 5.08 & 1.55 & 0.28 & Exotic \\
\hline Cataglyphis ibericus (Emery, 1906) & 0.00 & 1.11 & 0.00 & Native-common \\
\hline Cataglyphis rosenhaueri Santschi, 1925 & 0.61 & 0.00 & 0.00 & Native-common \\
\hline Cataglyphis velox Santschi, 1929 & 0.23 & 0.00 & 0.00 & Native-common \\
\hline Crematogaster auberti Emery, 1869 & 0.27 & 0.45 & 0.00 & Native-common \\
\hline Crematogaster scutellaris (Olivier, 1792) & 2.26 & 0.15 & 0.00 & Native-common \\
\hline Exotic Solenopsis sp. & 0.00 & 8.89 & 0.00 & Exotic \\
\hline Formica cunicularia Latreille, 1798 & 3.56 & 0.00 & 0.00 & Native-common \\
\hline Goniomma hispanicum (André, 1883) & 0.06 & 0.01 & 0.00 & Native-rare \\
\hline Hypoponera eduardi (Forel, 1894) & 0.74 & 0.23 & 0.00 & Native-common \\
\hline Lasius grandis Forel, 1909 & 21.95 & 10.11 & 0.00 & Native-common \\
\hline Lasius lasioides (Emery, 1869) & 0.02 & 0.00 & 0.00 & Native-rare \\
\hline Linepithema humile (Mayr, 1868) & 1.36 & 0.39 & 0.00 & Exotic \\
\hline Messor bouvieri Bondroit, 1918 & 0.01 & 1.50 & 0.00 & Native-common \\
\hline Messor barbarus (Linnaeus, 1767) & 0.42 & 1.29 & 0.00 & Native-common \\
\hline Messor celiae Reyes, 1985 & 0.01 & 0.00 & 0.00 & Native-rare \\
\hline Messor hesperius Santschi, 1927 & 0.00 & 0.00 & 0.07 & Native-common \\
\hline Messor structor (Latreille, 1798) & 0.05 & 0.00 & 0.00 & Native-common \\
\hline Monomorium andrei Saunders, 1890 & 0.00 & 0.05 & 0.00 & Native-rare \\
\hline Monomorium monomorium Bolton, 1987 & 0.13 & 0.00 & 0.00 & Native-rare \\
\hline Monomorium subopacum (F. Smith, 1858) & 0.00 & 6.04 & 0.00 & Native-common \\
\hline Myrmica aloba Forel, 1909 & 12.60 & 0.00 & 0.00 & Native-common \\
\hline Native Solenopsis spp. Westwood, 1840 & 4.40 & 3.74 & 0.78 & Native-common \\
\hline Nylanderia jaegerskioeldi (Mayr, 1904) & 0.00 & 6.16 & 3.85 & Exotic \\
\hline Paratrechina longicornis (Latreille, 1802) & 0.36 & 3.86 & 1.64 & Exotic \\
\hline Pheidole megacephala (Fabricius, 1793) & 0.00 & 0.00 & 89.13 & Exotic \\
\hline Pheidole pallidula (Nylander, 1849) & 10.43 & 10.69 & 0.02 & Native-common \\
\hline Plagiolepis schmitzii Forel, 1895 & 0.71 & 0.61 & 0.02 & Native-common \\
\hline Plagiolepis barbara Santschi, 1911 & 0.00 & 0.00 & 0.35 & Native-common \\
\hline Plagiolepis pygmaea (Latreille, 1798) & 4.50 & 0.60 & 0.00 & Native-common \\
\hline Plagiolepis sp. & 0.01 & 0.00 & 0.00 & Native-rare \\
\hline Proformica ferreri Bondroit, 1918 & 0.04 & 0.00 & 0.00 & Native-rare \\
\hline Pyramica membranifera (Emery, 1869) & 0.06 & 0.04 & 0.00 & Exotic \\
\hline Tapinoma erraticum (Latreille, 1798) & 1.42 & 0.44 & 0.00 & Native-common \\
\hline Tapinoma madeirense Forel, 1895 & 0.09 & 0.00 & 0.00 & Native-rare \\
\hline Tapinoma nigerrimum (Nylander, 1856) & 16.88 & 33.68 & 0.00 & Native-common \\
\hline Temnothorax racovitzai Bondroit, 1918 & 0.57 & 0.02 & 0.00 & Native-common \\
\hline Temnothorax recedens (Nylander, 1856) & 0.06 & 0.00 & 0.00 & Native-common \\
\hline Temnothorax pardoi Tinaut, 1987 & 0.19 & 0.01 & 0.00 & Native-rare \\
\hline Tetramorium bicarinatum (Nylander, 1846) & 0.01 & 0.00 & 0.00 & Exotic \\
\hline Tetramorium caldarium (Roger, 1857) & 0.00 & 0.00 & 0.61 & Exotic \\
\hline Tetramorium cf. caespitum (Linnaeus, 1758) & 3.21 & 0.92 & 0.00 & Native-common \\
\hline Tetramorium forte Forel, 1904 & 0.20 & 2.80 & 0.00 & Native-common \\
\hline Tetramorium lanuginosum Mayr, 1870 & 0.00 & 2.43 & 0.00 & Exotic \\
\hline Tetramorium semilaeve André, 1883 & 2.53 & 0.70 & 0.34 & Native-common \\
\hline
\end{tabular}

daler, 2006). Moreover, the vegetation in urban green areas frequently comes from tropical greenhouses and garden centers, which are sources of exotic species (Durán et al., 1994; Boer \& Vierbergen, 2008). In this study, it is worth pointing out that two of the invasive species: L. humile
(Argentine ant) and P. megacephala (Bigheaded ant), are listed by the IUCN as being in the top 100 of the "World's Most Invasive Alien Species" (Lowe et al., 2004). Both species have spread worldwide, beyond their original range (Roura-Pascual et al., 2011). Besides being a threat 


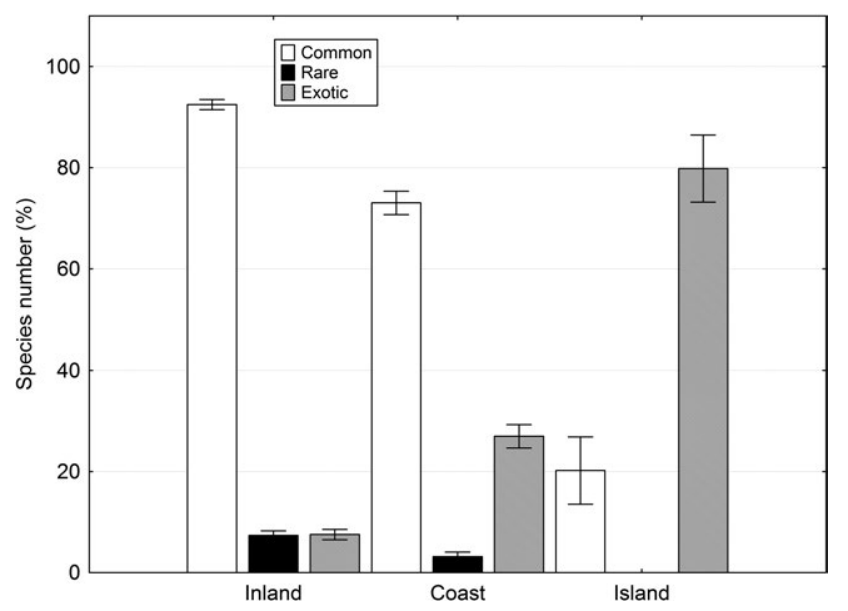

Fig. 2. Means percentages of the numbers of native-common, native-rare and exotic species caught at the inland, coastal and island locations. The catches of ten traps constituted a sample.

to native ant communities, they can cause severe economic problems (Vander Meer et al., 1990). In the present study L. humile was present at inland and coastal locations and its presence on Gran Canaria is recorded by other authors (Espadaler \& Bernal, 2003). P. megacephala, a widespread invasive tramp ant throughout the world, made up a large percentage (89.13\%) of the ants captured on Gran Canaria. The exotic pest species $N$. jaegerskioeldi and P. longicornis were mainly recorded along the coast (see also Martínez et al., 2007). The percentage of exotic species was significantly higher on Gran Canaria than along the coast and at inland locations. On the other hand, native species (both common and rare) showed the opposite tendency (Figs 2 and 3, Table 5). Ant communities at the three locations differed (Table 4). In terms of the percentage composition, the largest percentage of exotic species is found on islands

TABLE 4. Results of the forward-stepwise discriminant analysis: Grouping variable - type of location (island, coastal or inland); Independent variable - natural logarithms of species abundance. Observed classification indicates the level of overall classification expected on the basis of chance alone.

Forward-stepwise Discriminant: Wilks' $\lambda=0.01, \mathrm{p}<0.01$ Percentage of observed classifications Inland Coastal Island $\begin{array}{rrrr}100 & 83.33 & 100\end{array}$

No. of variables in model 11

\begin{tabular}{lccc}
\hline Independent variable $^{\mathrm{a}}$ & \multicolumn{3}{c}{ Wilk's $\lambda$ F-remove $\mathrm{p}$-value } \\
\hline P. megacephala $(\mathrm{E})$ & 0.15 & 976.61 & $<0.01$ \\
C. emeryi $(\mathrm{E})$ & 0.02 & 73.89 & $<0.01$ \\
M. hesperius $(\mathrm{N})$ & 0.01 & 36.19 & $<0.01$ \\
T. lanuginosum $(\mathrm{E})$ & 0.01 & 28.78 & $<0.01$ \\
Solenopsis sp $(\mathrm{E})$ & 0.01 & 29.93 & $<0.01$ \\
C. ibericus $(\mathrm{N})$ & 0.01 & 13.06 & $<0.01$ \\
P. longicornis $(\mathrm{E})$ & 0.01 & 25.17 & $<0.01$ \\
P. barbara $(\mathrm{N})$ & 0.01 & 12.97 & $<0.01$ \\
T. forte $(\mathrm{N})$ & 0.01 & 13.83 & $<0.01$ \\
N. jaegerskioeldi $(\mathrm{E})$ & 0.01 & 11.36 & $<0.01$ \\
M. subopacum $(\mathrm{N})$ & 0.01 & 7.61 & $<0.01$ \\
\hline
\end{tabular}

${ }^{\mathrm{a}} \mathrm{E}$ - exotic species; $\mathrm{N}$ - native species.

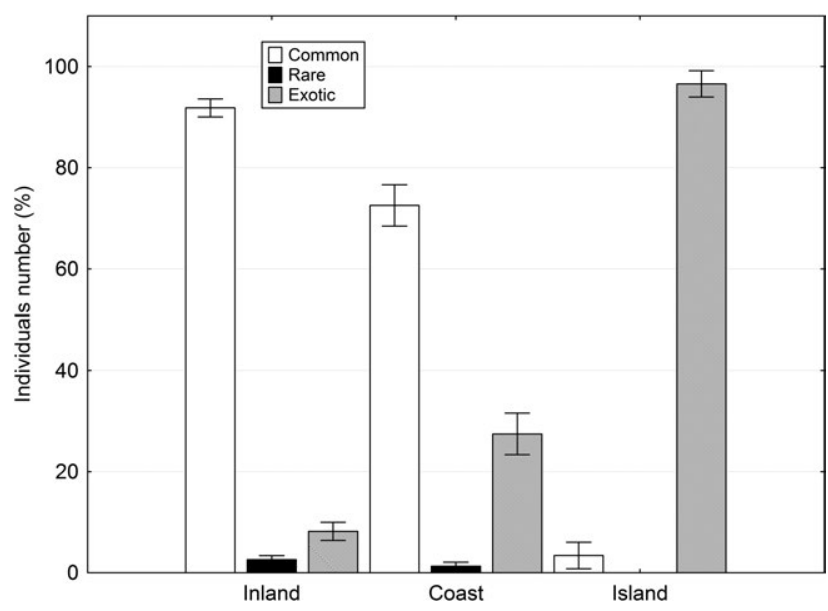

Fig. 3. Means percentages of the number of individuals of native-common, native-rare and exotic species caught at the inland, coastal and island locations. The catches of ten traps constituted a sample.

and in coastal locations for several reasons. For permanent settlement in a new area exotic species need first to reach the new location and, second, find the right habitat (Lonsdale, 1999). Common ways in which exotic species are introduced into an area are by trade, tourism and transportation (Levine \& D'Antonio, 2003; Ruiz \& Carlton, 2003; Perrings et al., 2005; Tatem, 2009). The Spanish coastal areas and cities on the island studied are top tourism destinations with a high level of international air and sea traffic, both for tourism and trade. Successful invasion by exotic species is enhanced by similarity in the physical environment between the source and target areas (Brown, 1989). Most of the exotic species captured originate from tropical or subtropical areas. In this study, the majority came from old world tropics, either Africa or Asia, and one of them, the Argentine ant, from South America (see in Brown \& Wilson, 1959; McGlynn, 1999; Bolton et al., 2006; Wetterer et al., 2007). The climate of islands and coastal cities favours these species, as the influence of the sea softens the temperatures, which are more extreme in the interior of the Iberian Peninsula.

Islands are a special case. If there is a universal pattern in the biology of invasions, it is that islands are highly sensitive to invasion (Brown, 1989; McGlynn, 1999; Mooney \& Cleland, 2001). This is particularly serious as islands are also refuges for many endemic species (Whittaker \&

TABLE 5. Kruskal-Wallis ANOVA by ranks: Grouping variable: location (inland, coastal, island); Dependent variable: First analysis, species richness of common, rare and exotic species; Second analysis, abundance of common, rare and exotic species.

Kruskal-Wallis ANOVA by ranks. Independent (grouping) variable: location (inland, coastal, island).

\begin{tabular}{lccc}
\hline Dependent variable & $\begin{array}{c}\text { Common } \\
\text { species }\end{array}$ & Rare & Exotic \\
\hline Species richness & $\begin{array}{l}\mathrm{H}=61.19 \\
(\mathrm{p}<0.01)\end{array}$ & $\begin{array}{l}\mathrm{H}=14.49 \\
(\mathrm{p}<0.01)\end{array}$ & $\begin{array}{c}\mathrm{H}=75.19 \\
(\mathrm{p}<0.01)\end{array}$ \\
Abundance & $\mathrm{H}=53.74$ & $\mathrm{H}=12.68$ & $\mathrm{H}=59.89$ \\
$(\mathrm{p}<0.01)$ & $(\mathrm{p}<0.01)$ & $(\mathrm{p}<0.01)$ \\
\hline
\end{tabular}


Fernández-Palacios, 2007; Walsh et al., 2012). This pattern is accounted for in terms of different aspects of island communities. First of all, communities on islands are species poor, which is considered to be an important factor favouring invasibility (Elton, 1958). It is also frequently suggested that invasive species face few strong competitors on islands; lower resistance from native species to invasion due to evolutionary isolation; no specific predators; and their distance from sources of colonizing species makes it more likely there are vacant niches on islands (see Levine \& D'Antonio, 1999). Nevertheless, this issue is very speculative (Colautti et al., 2004). Recent research indicates that the relationship between native and alien species richness is scale-dependent, and that habitats that favour native species richness may also favour alien species richness (Lonsdale, 1999; Borges et al., 2006). According to Herben (2005) and Daehler (2006), the factor that is positively associated with the invasibility of an island is not lower species richness but smaller species pools. This implies that there is a low probability that small species pools include fast growing species, which are more likely to exclude random invaders. Be that as it may, Lonsdale (1999) in his review of exotic plants from 184 sites around the world found that in terms of percentage composition there are three times more exotic species on islands than in mainland areas. In our study not only is this difference in the urban ant fauna much greater in terms of the richness of exotic or native species, but, it is even greater when the density of exotic or native individuals is considered (Figs 2 and 3). Although it is likely that our data for island urban green areas are biased by the dominance of $P$. megacephala on the only island included in this study, other studies also support the idea that island ecosystems are particularly vulnerable to invasive ants (see for example McGlynn et al., 1999; Espadaler \& Bernal, 2003; Wetterer et al., 2004; Ward et al., 2006; Rizali et al., 2010; Cerdá et al., 2011; Economo \& Sardat, 2012). In this regard, Gómez \& Espadaler (2006) report that on other Spanish islands the Balearics, $25 \%$ of the fauna is composed of exotic species, with the Argentine ant the most alarming species.

In contrast, rare species are more abundant in inland urban green areas. As mentioned above these species are considered to be rare because it is estimated that low numbers occur in Spain, and because of their endemic character or peculiar behaviour. In general, this group includes important species from a conservation point of view, such us: Proformica ferreri and Messor celiae, endemic species on the Iberian Peninsula; cryptic species, for example Monomorium andrei and Aphaenogaster dulcinea, or those belonging to the genus Temnothorax; species typical of mature ecosystems, that are more abundant in colder or woody habitats, such as Camponotus fallax or Lasius lasioides; or parasitic species Plagiolepis sp., a very rare species that is still in the process of being described (X. Espadaler, pers. commun. 2010).

The role of urban green areas in the conservation of biodiversity is a debatable issue (Fattorini, 2011). These areas can act as bridging locations, which enable alien species to colonize natural environments. Conversely, from a conservation point of view such areas may shelter high value species. The percentage of both types of species is influenced by many factors; for example, based on the results of this study, distance from the shore, however, this needs to be confirmed by similar studies carried out on islands and along coasts. Undoubtedly, it should be possible to manage urban green areas in such a way that the balance between the two types of species is altered to favour native ones (Blaustein, 2013; Susinsky et al., 2013).

ACKNOWLEDGEMENTS. We would like to thank A. Moreno, C. Ordoñez, A. Albarrán, J. García and M. Molina for field and laboratory assistance. We are grateful to F. Huggins for revising the English text and for her helpful comments. This research was partially supported by the Spanish Ministry of Education and Science, National Plan 2004-2007 I+D, Project "Role of ecological diversity in invasion resistance: the case of non-native ants in Mediterranean ecosystems" (CGL2004-00674/BOS).

\section{REFERENCES}

Adams L.W. 1994: Urban Wildlife Habitats: A Landscape Perspective. University Minnesota Press, Minneapolis, 208 pp.

Agosti D., Majer J.D., Alonso L.E. \& Schultz T.R. 2000: Ants: Standard Methods for Measuring and Monitoring Biodiversity. Smithsonian Institution Press, Washington DC, 280 pp.

Berman M., Andersen A.N., Hély C. \& Gaucherel C. 2013: Overview of the distribution, habitat association and impact of exotic ants on native ant communities in New Caledonia. PLoS ONE. doi:10.1371/journal.pone.0067245.

Bernadou A., Fourcassié V. \& Espadaler X. 2013. A preliminary checklist of the ants (Hymenoptera: Formicidae) of Andorra. - Zookeys 277: 13-23.

Blaustein R. 2013: Urban biodiversity gains new converts. BioScience 63: 72-77.

Boer P. \& Vierbergen G. 2008: Exotic ants in The Netherlands (Hymenoptera: Formicidae). - Entomol. Ber. 68: 121-129.

Bolton B., Alpert G., Ward P.S. \& Naskrecki P. 2006: Bolton's Catalogue of Ants of the World. Harvard University Press, Cambridge, $1844 \mathrm{pp}$.

Borges P.A.V., Lobo J.M., Azevedo E.B., Gaspar C., Melo C. \& NunEs L.V. 2006: Invasibility and species richness of island endemic arthropods: a general model of endemic vs. exotic species. - J. Biogeogr. 33: 169-187.

BROWN J.H. 1989: Patterns, modes and extents of invasions by vertebrates. In Drake J.A., Mooney H.A., di Castri F., Groves R.H., Kruger F.J., Rejmanek M. \& Williamson M. (eds): Biological Invasions: A Global Perspective. John Wiley \& Sons, New York, pp. 85-110.

BROwN K.S. JR. 1997: Diversity, disturbance, and sustainable use of Neotropical forests: insects as indicators for conservation monitoring. - J. Insect Conserv. 1: 25-42.

BuczkowsKi G. \& Richmond D.S. 2012: The effect of urbanization on ant abundance and diversity: a temporal examination of factors affecting biodiversity. PLOS ONE. doi:10.1371/journal. pone.0041729.

Carpintero S. \& Reyes-López J. 2014: Effect of park age, size, shape and isolation on ant assemblages in two cities of Southern Spain. - Entomol. Sci. 17: 41-51.

Carpintero S., Retana J., Cerdá X., Reyes J. \& Arias de ReyNA L. 2007: Exploitative strategies of the invasive Argentine ant (Linepithema humile) and native ant species in a southern Spanish pine forest. - Environ. Entomol. 36: 1100-1111. 
Cerdá X., Angulo E., Caut S. \& Courchamp F. 2012: Ant community structure on a small Pacific island: only one native species living with the invaders. - Biol. Invas. 14: 323-339.

Clarke K.M., Fisher B.L. \& LeBuhn G.L. 2008: The influence of urban park characteristics on ant (Hymenoptera, Formicidae) communities. - Urban Ecosyst. 11: 317-334.

Colautti R.I., Ricciardi A., Grigorovich I. \& Macisaac H.J. 2004: Is invasion success explained by the enemy release hypothesis? - Ecol. Lett. 7: 721-733.

DAEHLER C.C. 2006: Invasibility of tropical islands by introduced plants: Partitioning the influence of isolation and propagule pressure. - Preslia 78: 361-374.

Dekoninck W., Desender K. \& Grootaert P. 2008: Establishment of ant communities in forests growing on former agricultural fields: colonization and 25 years of management are not enough (Hymenoptera: Formicidae). - Eur. J. Entomol. 105: 681-689.

Ditchkoff S.S., SaAlfeld S.T. \& Gibson C.J. 2006: Animal behavior in urban ecosystems: modifications due to human-induces stress. - Urban Ecosyst. 9: 5-12.

Durán J.M., Sánchez A. \& Alvarado M. 1994: Problemática entomológica de las plantas ornamentales de la Exposición Universal de Sevilla 1992. - Bol. San. Veg. Plagas 20: 581-600 [in Spanish].

ECONOMO E.P. \& SARnAt E.M. 2012: Revisiting the ants of Melanesia and the taxon cycle: historical and human-mediated invasions of a tropical archipelago. - Am. Nat. 180: 1-16.

ELton C.S. 1958: The Ecology of Invasions by Animals and Plants. Methuen, London, $196 \mathrm{pp}$.

Espadaler X. \& Bernal V. 2003: Exotic ants in the Canary Islands (Hymenoptera, Formicidae). - Vieraea 31: 1-7.

FATTORINI S. 2011: Insect extinction by urbanization: a long term study in Rome. Biol. Conserv. 144: 370-375.

GómeZ K. \& Espadaler X. 2006: Exotic ants (Hymenoptera: Formicidae) in the Balearic Islands. - Myrmecol. News 8 $225-233$

Herben T. 2005: Species pool size and invasibility of island communities: a null model of sampling effects. - Ecol. Lett. 8 : 909-917.

Heterick B.E., Casella J. \& Majer J.D. 2000: Influence of Argentine and coastal brown ant (Hymenoptera: Formicidae) invasions on ant communities in Perth gardens, western Australia. - Urban Ecosyst. 4: 277-292.

Holway D.A., Lach L., Suarez A.V., Tsutsui N.D. \& Case T.J. 2002: The causes and consequences of ant invasions. - Annu. Rev. Ecol. Syst. 33: 181-233.

Hormigas.org 2013: https://www.formicidae.org/. Accessed 17 July 2013.

Jimenez J. \& Tinaut A. 1992: Mirmecofauna of the Sierra de Loja (Granada). - Orsis 7: 97-111.

Krushelnycky P.D., Holway D.A. \& LeBrun E.G. 2010: Invasion processes and causes of success. In Lach L., Parr C.L. \& Abbott K.L. (eds): Ant Ecology. Oxford University Press, Oxford, pp. 245-260.

LeVINE J.M. \& D'ANTONIO C.M. 1999: Elton revisited: a review of evidence linking diversity and invasibility. _ Oikos 87: 15-26.

LeVInE J.M. \& D'Antonio C.M. 2003: Forecasting biological invasions with increasing international trade. - Conserv. Biol. 17: 322-326.

Lizée M.H., Mauffrey J.F., Tatoni T. \& Deschamps-Cottin M. 2011: Monitoring urban environments on the basis of biological traits. - Ecol. Indic. 11: 353-361.

LONSDALE W.M. 1999: Global patterns of plant invasions and the concept of invasibility. - Ecology 80: 1522-1536.
Lososová Z., Chytrý M., TichÝ L., Danihelka J., Fajmon K., Hásek O., Kintrová K., LÁNíková D., OtÝPKová Z. \& ŘehoŘek V. 2012: Biotic homogenization of Central European urban floras depends on residence time of alien species and habitat types. - Biol. Conserv. 145: 179-184.

Lowe S., Browne M., Boudjelas S. \& De Poorter M. 2000: 100 of the World's Worst Invasive Alien Species A selection from the Global Invasive Species Database. IUCN/SSC Invasive Species Specialist Group (ISSG), Auckland, 11 pp.

MagurRan A.E. \& McGill B.J. (eds) 2010: Biological Diversity: Frontiers in Measurement and Assessment. Oxford University Press, Oxford, 345 pp.

Martínez M.D., Tinaut A. \& Ruano F. 2007: El género Paratrechina Motschoulsky, 1863, en España (Hymenoptera, Formicidae). - Boln. Asoc. Esp. Entomol. 31: 93-100 [in Spanish, English abstr.].

McGLYNN T.P. 1999: The worldwide transfer of ants: geographical distribution and ecological invasions. $-J$. Biogeogr. 26: 535-548.

McIntyre N.E., Rango J., Fagan W.F. \& Faeth S.H. 2001: Ground arthropod community structure in a heterogeneous urban environment. - Landsc. Urban Plan. 52: 257-274.

McKinNeY M.L. 2006: Urbanization as a major cause of biotic homogenization. - Biol. Conserv. 127: 247-260.

Menke S.B., Guénard B., Sexton J.O., Weiser M.D., Dunn R.R. \& SiLVERMAN J. 2011: Urban areas may serve as habitat and corridors for dry-adapted, heat tolerant species; an example from ants. - Urban Ecosyst. 14: 135-163.

Mooney H.A. \& CLELAND E.E. 2001: The evolutionary impact of invasive species. PNAS 98: 5446-5451.

NILON C.H. 2011: Urban biodiversity and the importance of management and conservation. — Lands. Ecol. Eng. 7: 45-52.

Passera L. 1994: Characteristics of tramp species. In Williams D.F. (ed.): Exotic Ants. Biology, Impact, and Control of Introduced Species. Westview Press, Oxford, pp. 23-43.

Perrings C., Dehnen-Schmutz K., Touza J. \& Williamson M. 2005: How to manage biological invasions under globalization. - Trends Ecol. Evol. 20: 212-215.

PisARski B. \& CZECHOWSKI W. 1978: Influence of urban pressure on the ant fauna. Mem. Zool. 29: 109-128.

Reyes-López J., Ordoñez C. \& Carpintero S. 2008: Relación actualizada de las hormigas alóctonas de Andalucía (Sur de España). - Boln. Asoc. Esp. Entomol. 32: 81-94 [in Spanish, English abstr.].

Ribas C.R., Campos R.B.F., Schmidt F.A. \& Solar R.C. 2012: Ants as indicators in Brazil: a review with suggestions to improve the use of ants in environmental monitoring programs. - Psyche doi: 10.1155/2012/636749.

Rizali A., Lohman D.J., Buchori D., Prasetyo L.B., Triwidodo H., Bos M.M., Yamane S. \& Schulze C.H. 2010: Ant communities on small tropical islands: effects of island size and isolation are obscured by habitat disturbance and 'tramp' ant species. - J. Biogeogr. 37: 229-236.

Roura-Pascual N., Brotons L., Peterson A.T. \& Thuiller W. 2009: Consensual predictions of potential distributional areas for invasive species: a case study of Argentine ants in the Iberian Peninsula. - Biol. Invas. 11: 1017-1031.

Roura-Pascual N., Hui C., IKeda T. et al. 2011: Relative roles of climatic suitability and anthropogenic influence in determining the pattern of spread in a global invader. - Proc. Natl. Acad. Sci. 108: 220-225.

Ruiz G.M. \& CARLton J.T. 2003: Invasive Species: Vectors and Management Strategies. Island Press, Washington DC, 287 pp. 
SÄUMEL I. \& KowARIK I. 2010: Urban rivers as dispersal corridors for primarily wind-dispersed invasive tree species. - Landsc. Urban Plan. 94: 244-249.

Sattler T., Obrist M.K., Duelli P. \& Moretti M. 2011: Urban arthropod communities: Added value or just a blend of surrounding biodiversity? - Landsc. Urban Plan. 3: 347-361.

Sноснат E. \& Ovadia O. 2011: Invasion, evenness, and species diversity in human-dominated ecosystems. In Lopez-Pujol J. (ed.): The Importance of Biological Interactions in the Study of Biodiversity. InTech, Rijeka, pp. 75-88.

Shochat E., Warren P.S., Faeth S.H., McIntyre N.E. \& Hope D. 2006: From patterns to emerging processes in mechanistic urban ecology. - Trends Ecol. Evol. 21: 186-191.

Slipinski P., Zminorski M. \& Czechowski W. 2012: Species diversity and nestedness of ant assemblages in an urban environment. — Eur. J. Entomol. 109: 197-206.

Stringer L.D., Stephens A.E.A., Suckling D.M. \& Charles J.G. 2009: Ant dominance in urban areas. - Urban Ecosyst. 12: 503-514.

Sushinsky J.R., Rhodes J.R., Possingham H.P., Gill T.K. \& FullER R.A. 2012: How should we grow cities to minimize their biodiversity impact? — Glob. Change Biol. 19: 401-410.

TАтем A.J. 2009: The worldwide airline network and the dispersal of exotic species: 2007-2010. - Ecography 32: 94-102.

Trueman I.C. \& Young C.H. 2012: Ecological value of urban environments. In Booth C.A., Hammond F.N., Lamond J.E. \& Proverbs D.G. (eds): Solutions to Climate Change Challenges in the Built Environment. Wiley-Blackwell, Oxford, pp. 99-112.

United Nations 2010: World Urbanization Prospects: The 2009 Revision. United Nations, Department of Economic and So- cial Affairs, Population Division, New York. http://esa.un.org/ unpd/wup/Documents/WUP2009_Press-Release_Final_Rev1. pdf. Accessed 18 July 2013.

Vander Meer R.K., Jaffe K. \& Cedeno A. (eds) 1990: Applied Myrmecology. A World Perspective. Westview Press, Boulder, $\mathrm{CO}, 741 \mathrm{pp}$.

Vepsäläinen K., Ikonen H. \& Koivula M.J. 2008: The structure of ant assemblages in an urban area of Helsinki, southern Finland. - Ann. Zool. Fenn. 45: 109-127.

Walsh J.C., Venter O., Watson J.E.M., Fuller R.A. \& BlackBURN T.M. \& Possingham H.P. 2012: Exotic species richness and native species endemism increase the impact of exotic species on islands. - Global Ecol. Biogeogr. 21: 841-850.

Ward D.F., Beggs J.R., Clout M.N., Harris R.J. \& O’Connor S. 2006: The diversity and origin of exotic ants arriving in New Zealand via human-mediated dispersal. — Divers. Distrib. 12: 601-609.

Wetterer J.K., Espadaler X., Wetterer A.L. \& Cabral S.G.M. 2004: Native and exotic ants of the Azores (Hymenoptera: Formicidae). - Sociobiology 44: 1-19.

Whitmore C., Crouch T.E. \& Slotow R.H. 2002: Conservation of biodiversity in urban environments: invertebrates on structurally enhanced road islands. - Afr. Entomol. 10: 113-126.

WhitTaker R.J. \& Fernández-Palacios J.M. 2007: Island Biogeography: Ecology, Evolution, and Conservation. Oxford University Press, Oxford, 285 pp.

Williams D.F. 1994: Exotic Ants: Biology, Impact, and Control of Introduced Species. Westview Press, Oxford, $332 \mathrm{pp}$.

WiLson E.O. \& HöLLDOBLER B. 2005: The rise of the ants: a phylogenetic and ecological explanation. — PNAS 102: 7411-7414.

Received July 22, 2013; revised and accepted February 10, 2014 Prepublished online May 6, 2014 